\title{
Gallium Ga 68-labeled MLN6907
}

National Cancer Institute

\section{Source}

National Cancer Institute. Gallium Ga 68-labeled MLN6907. NCI Thesaurus. Code C113805.

A radioconjug ate containing a monoclonal antibody directed against guanylyl cyclase $C$ (GCC) labeled with the radio isotope gallium Ga 68 , with positron emission tomography (PET) imaging activity. The monoclonal antibody moiety of MLN6907 selectively binds to GCC, a transmembrane receptor normally found on intestinal cells and dopaminergic neurons in the brain, that is also overexpressed on the surface of a variety of cancer cells. Upon internalization of the agent and PET, tumors expressing GCC can be visualized. 